\title{
Detection of nano- and micro-sized particles in routine biopsy material - pilot study
}

\author{
Jana Dvorackovaa , Hana Bielnikova ${ }^{b}$, Jana Kukutschova ${ }^{c, d}$, Pavlina Peikertovac, Peter Filip ${ }^{c, e}$, Karol Zelenik ${ }^{b}$, Pavel Kominek \\ Magdalena Uvirova ${ }^{f}$, Jana Pradna ${ }^{g}$, Zuzana Cermakova ${ }^{a}$, Igor Dvoracek ${ }^{a}$
}

Background. Nanotechnology is receiving enormous funding. Very little however is known about the health dangers of this technology so far. Chronic tonsillitis is one of a number of diseases called idiopathic. Among other factors, the tonsils are exposed to suspended particles in inhaled air including nano particles. The objective of this study was to detect and evaluate metallic particles in human tonsil tissue diagnosed with chronic tonsillitis and in amniotic fluid as a comparison.

Methods. Scanning electron microscopy with energy dispersive X-ray spectroscopy (SEM-EDX) was used for identification of solid particles in a total of 64 samples of routinely analyzed biopsy and cytologic material.

Results. Almost all samples were found to contain solid particles of various metals. The most frequent, regardless of diagnosis, were iron, chromium, nickel and aluminium. The size, determined using SEM, varied from around $500 \mathrm{~nm}$ to $25 \mu \mathrm{m}$. The majority formed aggregates of several micrometers in size but there were a significant number of smaller (sub-micrometer or nano-sized) particles present. The incidence of metallic particles was similar in child and adult tissues. The difference was in composition: the presence of several metals in adults was due to occupational exposure.

Conclusions. The presence of metallic particles in pathologically altered tissues may signal an alternative causation of some diseases. The ethiopathogenic explanation of these diseases associated with the presence of nano-sized particles in the organism has emerged into a new field of pathology, nanopathology.

Key words: pathologic processes, inflammation, metals, particles

Received: July 9, 2012; Accepted: November 13, 2012; Available online: December 10, 2012

http://dx.doi.org/10.5507/bp.2012.104

${ }^{a}$ Faculty of Medicine, University of Ostrava, Syllabova 19, 70300 Ostrava, Czech Republic

${ }^{b}$ Faculty Hospital Ostrava, 17.listopadu 1790, 70852 Ostrava

'Nanotechnology Center, VSB - Technical University Ostrava, 17. listopadu 15, 70833 Ostrava

${ }^{d}$ Regional Materials Science and Technology Centre, VSB - Technical University Ostrava, 17. listopadu 15, 70833 Ostrava

${ }^{e}$ Center for Advanced Friction Studies, Southern Illinois University at Carbondale, Carbondale, IL 62901, USA

${ }^{f}$ CGB Laboratory Ltd., Korenskeho 10, 70300 Ostrava

IInstitute of Pathology, Ceske Budejovice Hospital, B. Nemcove 585/54, 37001 Ceske Budejovice

Corresponding author: Jana Dvorackova, e-mail: jana.dvorackova@fno.cz

\section{INTRODUCTION}

Nano-sized particles $(<100 \mathrm{~nm})$ have properties that may pose risks to human health and the environment. An Italian research team has discussed the potential association between some oncological changes, inflammatory responses, cardiovascular and other cryptogenic diseases and the presence of nano-sized particles deposited in various tissues within the human body ${ }^{1}$. Nano-sized particles have been described in many studies to be significantly different in terms of their reactivity and behavior in various environmental media (air, water, and soil). This particle fraction settles by gravitation very slowly when emitted into the atmosphere, and thus the risk of inhalation exposure is higher than micrometer particles. These particles below $100 \mathrm{~nm}$ in diameter are referred to as nanoparticles or ultrafine particles. The term nanoparticle is used for engineered particles, i.e. products of nanotechnologies with a wide range of applications in medicine, electronics, cosmetics, drug delivery, the food industry, automotive industry and many others. The term ultrafine particles denotes unintentionally produced particles, which are most often emitted by anthropogenic activities ${ }^{2}$. Road traffic was found to contribute significantly to nano-particulate air pollution caused by diesel emissions ${ }^{3}$, and wear of brakes ${ }^{4}$ and tires ${ }^{5}$. Pyrometallurgical plants produce particulate emissions down to $10 \mathrm{~nm}$ in size containing $\mathrm{Fe}, \mathrm{Cr}, \mathrm{Mn}$, $\mathrm{Ni}, \mathrm{Cu}, \mathrm{Zn}$ and $\mathrm{W}\left(\right.$ ref. $^{6}$ ). Various metals are abundant components of particulate air pollution, e.g. wear of automotive brake pad releases $\mathrm{Fe}, \mathrm{Cu}, \mathrm{Ba}$, and $\mathrm{Sb}$ into the environment ${ }^{7}$. Various anthropogenic processes, such as cigarette smoking, may produce these metal-containing particles where the smoke may contain metals such as $\mathrm{Al}, \mathrm{Cd}, \mathrm{Ni}, \mathrm{Pb}$, and $\mathrm{Cu}$ in the form of very fine particles ${ }^{1}$. Metals, such as $\mathrm{Fe}, \mathrm{Cu}, \mathrm{Zn}, \mathrm{Sn}, \mathrm{Ba}, \mathrm{Sb}$ and Ti are being emitted as nano-sized particles by the combustion of fossil fuels. Nano-sized particles are also being produced by natural sources, such as volcanic activity and forest fires. Whether these nano-sized particles pose any health risk, and what particle size, shape and composition is the most harmful to human health, are unclear.

Nanopathology deals with interactions between 
the organism and nano-sized particles from several nanometers in size to several hundreds of nanometers. Nanopathologic diseases, are referred to as diseases which originate in the penetration of nano-sized, mainly inorganic, particles and deposition of micro-sized aggregates in the human and animal body. The first references to these nanopathologies were associated mainly with military patients who developed illness in connection with war conflicts like the "Gulf War Syndrome" and "Balkan Syndrome", etc. Medical examination data of firefighters and rescuers exposed to fine and ultrafine dust emitted after the World Trade Center collapse in New York have also contributed to knowledge on the health impact of fine metallic particle inhalation ${ }^{1}$. Metals are known for their carcinogenic potential due to inhibition of the DNA repair mechanisms ${ }^{8}$. A number of studies also confirm the ability of some metals (e.g. Fe) to induce inflammation, tissue damage and cancer by production of reactive oxygen species - free radicals ${ }^{9}$. However, most studies on the health impact of nanomaterials use animal models or cell cultures.

There is currentl research on the preparation, application and characterization of nano-sized particles, but very little on the potential health risks associated with the production and emissions of these particles into the environment. Nano-sized particles may enter the body via inhalation, digestion and skin penetration. In the body, they can be translocated via the blood and lymphatic system to sensitive target tissues/organs ${ }^{1,2,10}$. Transport of nano-sized particles across the blood-brain barrier and/or olfactory pathway has been found in some animal studies ${ }^{11,12}$. The health effects of nano-sized particles are well-documented in various clinical and epidemiological studies. However, the toxicity has been studied using animal models such as rats, rabbits, and monkeys or tissue cultures ${ }^{13-17}$.

The aim of this study was to evaluate the presence of metal-bearing particles in human tonsil tissues and amniotic fluid samples which were chosen for the potential exposure of fetuses to particles suspended in these fluids.

\section{EXPERIMENTAL}

Several types of paraffin-fixed human tissues and unfixed body fluid samples taken from routine biopsies carried out at the Faculty Hospital in Ostrava were analyzed. Tissue samples taken for further analysis were approximately $1 \mathrm{~cm}^{3}$ in size. In order to remove the paraffin, the samples were treated with xylene and acetone and then heated in a thermostat at $58{ }^{\circ} \mathrm{C}$ for $48 \mathrm{~h}$ to dry the sample for microscopic analysis. All chemicals used for tissue processing were of analytical grade.

During the sample processing for microscopic analysis, ceramic knives were used to prevent contamination of samples by wear particles from stainless steel instruments. These samples were coated with $\mathrm{Au}$ and $\mathrm{Pd}$ for microscopic analysis using a scanning electron microscope with energy dispersive spectroscopy (SEM-EDX PHILIPS XL 30) operating at $30 \mathrm{keV}$ allowing for analysis of elemental composition. Samples were analyzed in back-scattered electron mode (BSE), which enables visual detection of different elemental composition compared to the background, i.e. tissue. Body fluid samples (amniotic fluids) were analyzed in the same way after centrifugation and desiccation at room temperature on a glass plate.

Selection of tissue samples was focused mainly on the respiratory tract and nasopharynx due to the assumption that this is the main entrance route of inhaled particles into an organism. Amniotic fluids were selected after the finding that metallic particles may be detected in the tonsil tissue of stillborn fetuses. The most abundant tissues analyzed were tonsil tissues diagnosed with tonsillitis. Within the group, almost one third of samples were tissues from patients diagnosed with chronic tonsillitis, living in a non-industrial region of the Czech Republic with significantly lower pollution. The second group of samples was tonsillar squamous cell carcinoma samples. Further, stillborn fetal tonsils, pulmonary tissue diagnosed with intersticial fibrosis, one sample of brain tissue diagnosed with glioblastoma, and twelve samples of amniotic fluids were analyzed. A summary of single types of samples is presented in Table 1.

Table 1. Number and percentage of single sample types.

\begin{tabular}{lcc}
\hline Type of tissue & $\begin{array}{c}\text { Number } \\
\text { of samples } \\
\text { analyzed }\end{array}$ & $\begin{array}{c}\text { Percentage } \\
{[\%]}\end{array}$ \\
\hline $\begin{array}{l}\text { Tonsillar tissue } \\
\text { with tonsillitis }\end{array}$ & 39 & 61 \\
$\begin{array}{l}\text { Tonsillar squamous cell } \\
\text { carcinoma }\end{array}$ & 11 & 17 \\
$\begin{array}{l}\text { Tonsillar tissue } \\
\text { of stillborn fetuses }\end{array}$ & 2 & 3 \\
Amniotic fluids & 12 & 19 \\
\hline
\end{tabular}

\section{RESULTS}

Various metal-bearing solid particles were detected in all samples analyzed as single micro-sized particles or aggregates consisting of many submicron particles reaching the nano-scale. The incidence of metallic particles in tissues with tonsillitis (e.g. from children and adolescent patients) was comparable to tumor samples of tonsillar tissue, mainly from patients over 40 years old. Elemental analysis using EDX determined the presence of metals; however, we can assume that metals, such as $\mathrm{Fe}, \mathrm{Zn}, \mathrm{Pb}$, $\mathrm{Sn}$, and $\mathrm{Al}$, are present in the form of their oxides or other compounds. Several examples of particles detected are presented in Fig. 1 - 4. The most abundant element was iron separately or in the form of iron alloys together with $\mathrm{Cr}$ and Ni. When compared to detected elemental iron, steel particles were also different in morphology. While iron aggregates were relatively round and formed of submicron particles, the steel particles were up to several micrometers in size with sharp edges, which is typical for 
Table 2. Metals and metalloids detected in particular sample types.

\begin{tabular}{lll}
\hline Sample & Characteristics & Metals and semi-metals detected \\
\hline Tonsillar tissue & Chronic tonsillitis - children & $\begin{array}{l}\text { Fe, Fe-Cr-Ni, Fe-Cr, Fe-Mn-Ni, Fe-Ni, Fe-Mn, Si-Al-Fe, Si-Al, Cu, } \\
\text { Al, Zn, Sn, Pb, Ti, Ni, Ba }\end{array}$ \\
& $\begin{array}{l}\text { Chronic tonsillitis - adults } \\
\text { Fe, Fe-Cr-Ni, Fe-Cr, Fe-Ni, Cu, Al, Zn, Mn, Ti }\end{array}$ \\
Squamous cell carcinoma & Fe, Fe-Cr-Ni, Fe-Cr, Al, Co, Cu, Ni, Sn, Ti, Zn, W \\
Stillborn fetuses & Fe, Cu, Zn, Al, Ba \\
\hline
\end{tabular}

$\mathrm{Fe}-\mathrm{Cr}-\mathrm{Ni}, \mathrm{Fe}-\mathrm{Cr}, \mathrm{Fe}-\mathrm{Mn}-\mathrm{Ni}, \mathrm{Fe}-\mathrm{Ni}, \mathrm{Fe}-\mathrm{Mn}$ - metals present in form of alloys

$\mathrm{Si}-\mathrm{Al}, \mathrm{Si}-\mathrm{Al}-\mathrm{Fe}$ - elements indicating presence of aluminosillicates

particles produced by mechanical wear ${ }^{4}$. We can see from Fig 1 and 2 that the aggregates consisted of nanoparticles. Based on SEM-EDX analysis of tissue cross sections it is evident from the experimental data that metallic aggregates are located inside the lymphoid elements and epithelial cells of tumors. Uniquely, tungsten particles were detected inside red blood cells or blood vessels. A summary and the frequency of metals and metalloids detected in particular groups of samples are shown in Table 2.
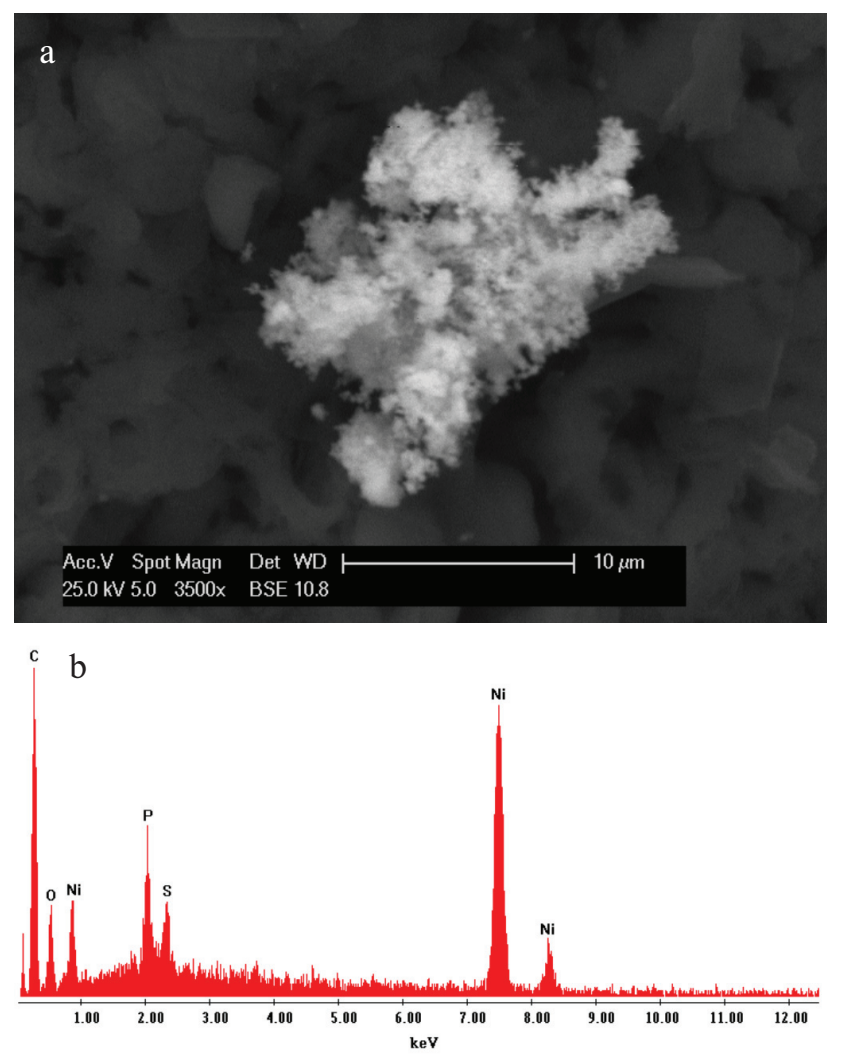

Fig. 1. SEM image (a) with corresponding EDX spectrum (b) of agglomerate detected in squamous cellular carcinoma tissue of 56 year old patient working as driver, previously as miner.

\section{DISCUSSION AND CONCLUSIONS}

Tissue from chronic tonsillitis, squamous cell carcinoma and several other tissue types were found to contain various metal-bearing solid particles. One hypothesis is that tissue irritation by nano- and micro-sized particles leads to inflammation and/or cell proliferation. In 57 samples of a total 64 analyzed by SEM, various metalbearing solid particles were found. The size of detected particles/aggregates varied approximately from several hundreds of nanometers to $25 \mu \mathrm{m}$. A large number of aggregates contained nano-sized particulate matter (Fig. $1 \mathrm{a}$ and $2 \mathrm{a}$ ). The real size of the smallest particles present can be determined using transmission electron micros-

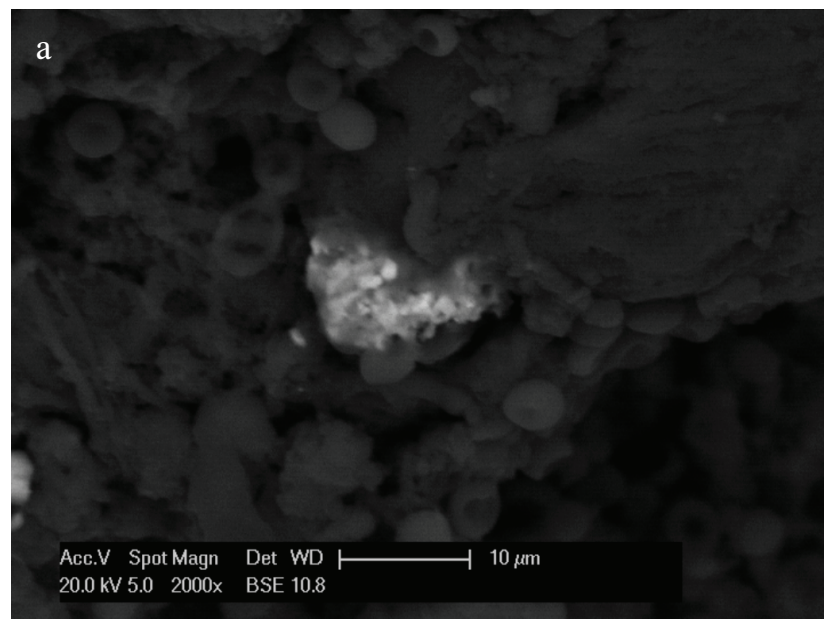

b

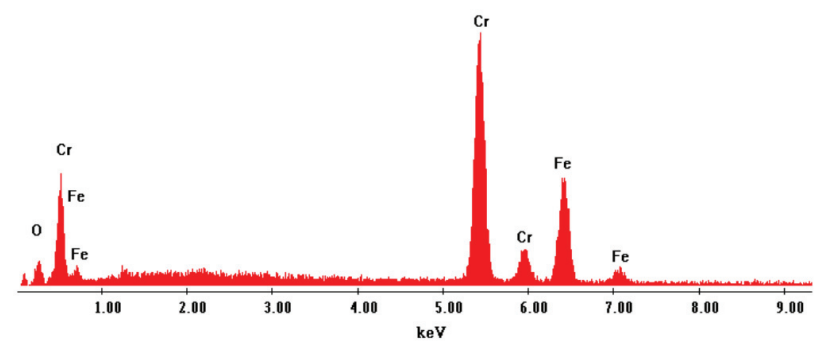

Fig. 2. SEM image of particle/agglomerate (a) with corresponding EDX spectrum (b) revealing chromium and iron detected in tissue diagnosed with tonsillitis chronica of 38 year old patient working as locksmith. 


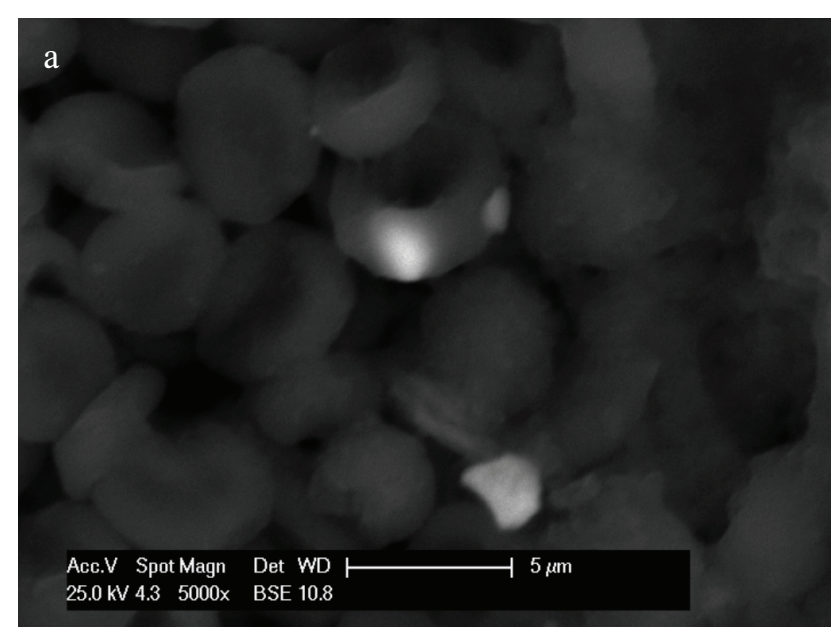

b

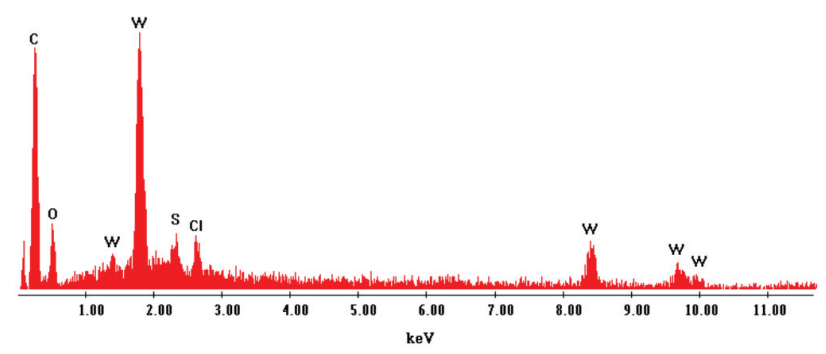

Fig. 3. SEM image of erythrocyte (a) with corresponding EDX spectrum (b) of point analysis in bright spot detecting tungsten $(\mathrm{W})$ inside the cell in glioblastoma cerebri of 62 year old patient working as welder.

copy (TEM). However, there are significant difficulties in detecting these metallic particles in tissue samples using this technique. Samples prepared for purposes of TEM analysis are in the form of ultrathin sections, and there is a much lower probability that solid particles or their aggregates will be found. We found that particles were not distributed homogeneously within tissues and therefore; SEM analysis using the BSE mode is more suitable for analysis of the higher surface area of a sample.

The most abundant element in all tissues was iron together with chromium and nickel, which indicates the presence of alloy particles (Fig. 2). Nevertheless, it is not clear what the origin of these particles is. The next most abundant element was iron (without chromium or nickel), which is probably present in the form of various oxides and may be derived from various anthropogenic sources, e.g. braking of automobiles ${ }^{4}$ and pyrometallurgy. Iron in the form of alloys or alone was detected in almost all sample types analyzed (tonsillitis, carcinoma, amniotic fluids). Several particles containing $\mathrm{Si}$ together with $\mathrm{Al}$ were found, which may signalize the presence of aluminosilicates from soil. Elements such as $\mathrm{Cu}$ and $\mathrm{Al}$ are known to be emitted with cigarette smoke ${ }^{1}$. These elements were found in the tonsils of children whose parents smoke or actively smoking adolescents and adults. Copper was also detected in tissues in children and adults living near busy roads as well as in tissues of several drivers
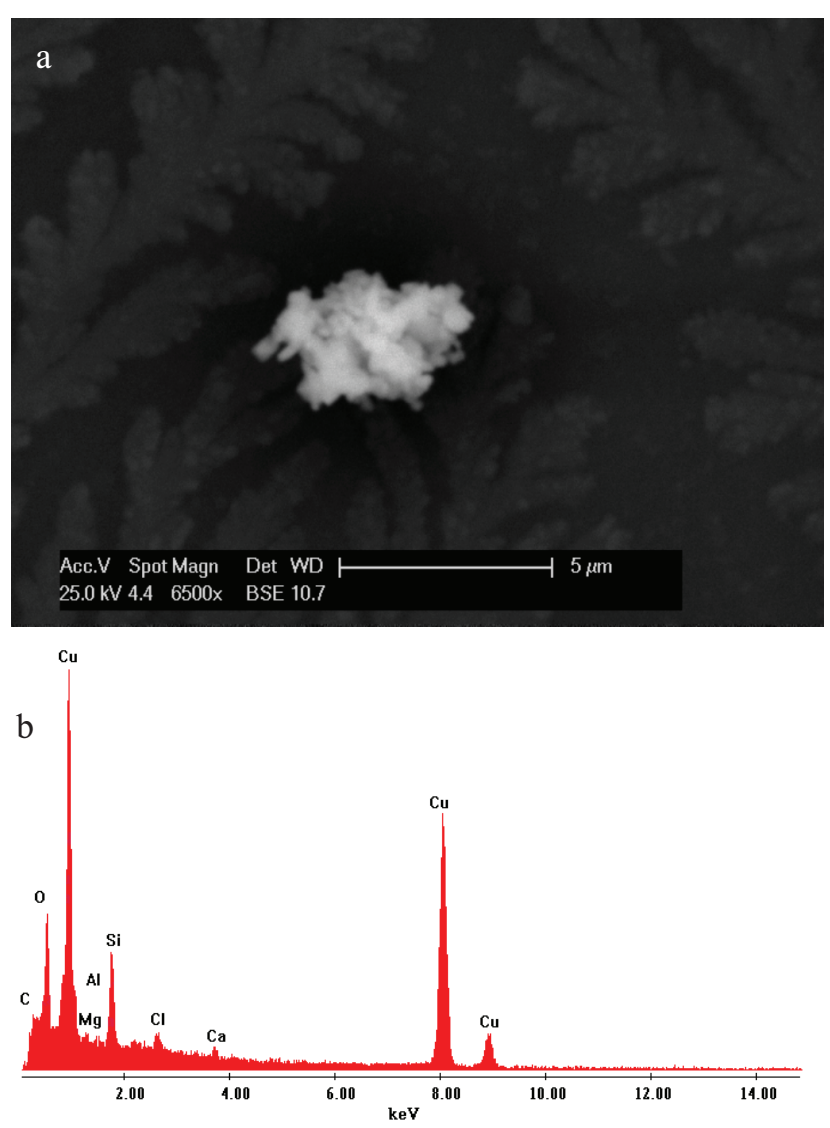

Fig. 4. SEM image (a) with corresponding EDX spectrum (b) of agglomerate detected in dried amniotic fluid.

and traffic police officers. This may be among others due to environmental and occupational exposure to particles generated by the braking of automobiles ${ }^{7}$. Surprisingly, the elemental composition of particles detected in tissues with tonsillitis was comparable to elements detected in tissues with squamous cell carcinoma. The only difference was presence of tungsten in the tonsil tissue of a welder what was not detected in any sample of child tissue or tissue of adults with different occupation. Gas tungsten arc welding is being used for many industrial applications. The temperature during welding may reach up to $6000{ }^{\circ} \mathrm{C}$ and the melting point of the tungsten is about $3500{ }^{\circ} \mathrm{C}$. Therefore, we can assume that tungsten may evaporate and form the finest particles $(10-100 \mathrm{~nm})$ by condensation $^{18}$. Moreover, one glioblastoma (grade IV) of a patient working as a welder contained tungsten particles inside a red blood cell (Fig. 3). Tjalve and Henriksson reported that welding particles that deposit in the nasal/head airway region may reach the brain via olfactory transport and thus bypass the blood-brain barrier ${ }^{19}$.

The assumption that tonsils of stillborn fetuses would be free from nano-sized particles was incorrect. In accordance with the literature ${ }^{20,21}$, the presence of nanosized particles in amniotic fluid samples, as a proof of transplacentar transport, helped to explain nano-sized particles detected in tonsillar tissue samples of stillborn fetuses. However, tonsils of a fetus are in direct contact 
with amniotic fluid due to digestion. Metals such as $\mathrm{Cu}$ (Fig. 4), Fe, and $\mathrm{Zn}$ were detected in amniotic fluids analyzed. Blood circulation of nano-sized particles and their translocation to sensitive target tissues within the body was experimentally proved by tungsten particles detected inside an erythrocyte of glioblastoma (Fig. 3) and the presence of agglomerates of various metal-based particles in lung septa of fibrotic tissue.

It is unknown whether the presence of detected metal-based particles will lead to health problems and the diseases diagnosed. Nevertheless, Hunt et al. analyzed archival autopsy tissues from persons who died from smog exposure during a London smog event in 1952. Using electron microscopy analysis they revealed a predominance of retained soot and metal-bearing particles. Based on the experimental data, they stated that exposure to atmospheric particulate matter, even at low concentrations, is clearly linked to increased mortality and morbidity ${ }^{22}$. Phillips et al. analyzed autopsy samples of a patient operating a metal arc process for spraying nickel onto bearings who died of respiratory failure 13 days after exposure. Microscopic analysis using TEM revealed nickel particles from 4 to $25 \mathrm{~nm}$ inside macrophages in the lung tissue ${ }^{23}$. Recent studies described the health impact of nano-sized particles in terms of genotoxicity, i.e. chromosomal aberrations, DNA breakage, point mutations and alteration of gene expression $^{8,24-27}$.

Recently, some studies have shown that nano-sized particles are able to cross pores of the nuclear membrane of a cell, which indicates potential risk of genetic information damage and subsequent cancerogenesis ${ }^{26}$. The presence of metallic nano-sized particles in the structures of spinocellular carcinoma supports the hypothesis of a number of studies regarding their potential cancerogenic effect. However, the exact mechanism is not understood.

Based on the experimental data, it can be concluded that chemical analysis of various human tissue samples may be a useful tool for predicting the potential causes of disease, especially idiopathic diseases.

\section{ACKNOWLEDGEMENT}

The paper was written in the framework of the "Regional Materials Science and Technology Centre" supported by the Operational Programme "Research and Development for Innovations" project reg. No. CZ.1.05/2.1.00/01.0040, and under the project Nanotechnology - the basis for international cooperation, supported by the Operational Programme 'Education for competitiveness' and financed by the Structural Funds and from the state budget of the Czech Republic, reg. No. CZ.1.07/2.3.00/20.0074. The authors thank Mr. Chad Waters and Mr. Daniel Casten for English corrections and Mrs. Marie Heliova for SEM analyses.

Autorship contributions: ZC, ID, MU: literature search; JD, HB: manuscript writing; JD: study design; KZ, PK, JP: data collection; JK, PP: data analysis; JD,
JK, HB, PP: data interpretation; JK, PP, HB: figures; JD, $\mathrm{PF}$ : final approval.

Conflict of interest statement: The authors stated that there are no conflicts of interest regarding the publication of this article.

\section{REFERENCES}

1. Gatti AM, Montanari S. Nanopathology: the health impact of nanoparticles. Singapore: Pan Stanford Publishing Pte. Ltd.;2007. p. 312.

2. Oberdörster G, Oberdörster E, Oberdörster J. Nanotoxicology: An Emerging Discipline Evolving from Studies of Ultrafine Particles, Environ Health Perspect 2005;113:823-39.

3. Liati A, Eggenschwiler PD. Characterization of particulate matter deposited in diesel particulate filters: Visual and analytical approach in macro-, micro- and nano-scales. Combust Flame 2010;157:165870.

4. Kukutschová J, Moravec P, Tomášek V, Matějka V, Smolík J, Schwarz J, Seidlerová J, Šafářová K, Filip P. On airborne nano/micro-sized wear particles released from low-metallic automotive brakes. Environ Pollut 2011;159:998-1006.

5. Kreider ML, Panko JM, McAtee BL, Sweet LI, Finley BL. Physical and chemical characterization of tire related particles: Comparison of particles generated using different methodologies. Sci Tot Environ 2010;408:652-9.

6. Cheng YH, Chao YC, Wu CH, Tsai CJ, Uang SN, Shih TS. Measurements of ultrafine particle concentrations and size distribution in an iron foundry. J Hazard Mater 2008;58:124-30.

7. Kukutschová J, Roubíček V, Malachová K, Pavlíčková Z, Holuša R, Kubačková J, Mička V, MacCrimmon D, Filip P. Wear mechanism in automotive brake materials, wear debris and its potential environmental impact. Wear 2009;267:807-17.

8. Hartwig A. Carcinogenicity of metal compounds: possible role of DNA repair inhibition. Toxicol Lett 1998;102-103:235-9.

9. Okada S. Iron-induced tissue damage and cancer: The role of reactive oxygen species-free radicals. Pathol Internat 1996;46:311-32.

10. Gatti AM, Montanari S, Monari E, Gambarelli A, Capitani F, Parisini B. Detection of micro- and nano-sized biocompatible particles in the blood. J Mater Sci Mater Med 2004;15:469-72.

11. Claderon-Garciduenas L, Azzarelli B, Acuna H, Garcia R, Gambling TM, Osnaya N, Monroy S, Tizapantzi MDR, Carson J, VillarrealCalderon A, Rewcastle B. Air pollution and brain damage. Toxicol Pathol 2002;30(3):373-89.

12. Geiser M, Kreyling WG. Deposition and biokinetics of inhaled nanoparticles. Part Fib Toxicol 2010;7(2):1-17.

13. Hu X, Cook S, Wang P, Hwang H, Liu X, Williams QL. In vitro evaluation of cytotoxicity of engineered carbon nanotubes in selected human cell lines. Sci Tot Environ 2010;408:1812-7.

14. Shvedova AA, Kisin ER, Porter D, Schulte P, Kagan VE, Fadeel B, Castranova V. Mechanism of pulmonary toxicity and medical applications of carbon nanotubes: Two face of Janus? Pharmacol Therap 2009;121:192-204.

15. Firme CP, Bandaru PR. Toxicity issues in the application of carbon nanotubes to biological systems. Nanomed Nanotech Biol Med 2010;6:245-56.

16. Peters K, Unger RE, Kirkpatrick CJ, Gatti AM, Monari E. Effects of nano-scaled particles on endothelial cell function in vitro: Studies on viability, proliferation and inflammation. J Mater Sci Mater Med 2004;15:321-5.

17. Hansen T, Clermont G, Alves A, Eloy R, Brochhausen C, Boutrand JP, Gatti AM, Kirkpatrick CJ. Biological tolerance of different materials in bulk and nanoparticulate form in a rat model: Sarcoma development by nanoparticles. J Roy Soc Interface 2006;3:767-75.

18. Antonini JM, Santamaria AB, Jenkins NT, Albini E, Lucchini R. Fate of manganese associated with the inhalation of welding fumes: Potential neurological effects. Neurotoxicology 2006;27:304-10.

19. Tjalve $\mathrm{H}$, Henriksson J. Uptake of metals in the brain via olfactory pathways. Neurotoxicology 1999;20:181-96.

20. Reichrtová E, Dorociak F, Palkovicová L. Sites of lead and nickel accumulation in the placental tissue. Hum Exp Toxicol 1998;17(3):176-81. 
21. Kaiglová A, Reichrtová E, Adamcáková A, Wsólová L. Lactate dehydrogenase activity in human placenta following exposure to environmental pollutants. Physiol Res 2001;50(5):525-8.

22. Hunt A, Abraham JL, Judson B, Berry CL. Toxicologic and epidemiologic clues from the characterization of the 1952 London smog fine particulate matter in archival autopsy lung tissues. Environ Health Perspect 2003;111(9):1209-14.

23. Phillips Jl, Green FY, Davies JCA, Muray J. Pulmonary and systemic toxicity following exposure to nickel nanoparticles. Amer J Ind Med 2010;53(8):763-7.
24. Mehta M, Chen LCh, Gordon T, Rom W, Tang MS. Particulate matter inhibits DNA repair and enhances mutagenesis. Mutat Res 2008;657:116-21.

25. Chen F, Vallyathan V, Castranova V, Shi X. Cell apoptosis induced by carcinogenic metals. Mol Cell Biochem 2001;222:183-8.

26. Beyersmann D, Hartwig A. Carcinogenic metal compounds: recent insight into molecular and cellular mechanisms. Arch Toxicol 2008;82:493-512.

27. Stone V, Johnston H, Clift MJD. Air Pollution, Ultrafine and Nanoparticle Toxicology: Cellular and Molecular Interactions. IEEE Transact Nanobiosci 2007;6(4):331-40. 